\title{
Effects of Crude Oil on Biomass and Protein Production by Aquatic Bacteria
}

\author{
Nwokoro, 0. ${ }^{1}$ and Onyebueke, M. ${ }^{2}$ \\ 1,2Industrial Microbiology and Biotechnology Laboratory, Department of Microbiology, University of \\ Nigeria, Nsukka, Nigeria \\ *Corresponding Author's Contact: ogbonnaya.nwokoro@unn.edu.,ng Tel No: +2348034402414
}

\begin{abstract}
Some effects of Bonny light crude oil on the biomass and protein production by three aquatic bacteria namely, Pseudomonas aeruginosa, Aeromonas hydrophyla and Vibrio fisheri were investigated. The species showed different responses to the toxic influences of various crude oil concentrations. The growth response was measured spectrophotometrically using optical density (OD) at 600nm. Pseudomonas aeruginosa responded positively to all crude oil levels. A general assessment indicated that $2 \%$ (v/v) crude oil concentration stimulated maximum biomass and protein production of this organism. Lower biomass and protein yields were observed at reduced crude oil levels. Biomass production decreased gradually among Aeromonas hydrophyla and Vibrio fisheri in comparison to the control. Biomass of Aeromonas hydrophyla increased from $0.1\left(O D_{600 \mathrm{n}}\right)$ at $0 \mathrm{~h}$ to 0.58 after $20 \mathrm{~h}$ at $0.5 \%$ crude oil concentration. This level gradually declined to 0.03 after 20 h cultivation at $1.5 \%$ crude oil concentration. Maximum decline in optical density of this organism was observed at crude oil concentration of 2.0\%. Protein levels for Aeromonas hydrophyla decreased from $0.12 \mathrm{mg} / \mathrm{mL}$ after $20 \mathrm{~h}$ at crude oil concentration of $0.5 \%$ to $0.06 \mathrm{mg} / \mathrm{mL}$ after $20 \mathrm{~h}$ at maximum crude oil concentration of $2 \%$. The biomass of Vibrio fisheri increased slightly from $0.1\left(0 D_{600 \mathrm{~nm}}\right)$ at 0 h to 0.03 after 20 h at $0.5 \%$ crude oil level. Further decreases in OD values of this organism occurred progressively as the crude oil concentration was increased. Lowest protein yield for this organism was observed at a crude oil concentration of $2 \%$ at which the least protein production of $0.03 \mathrm{mg} / \mathrm{mL}$ was produced after 20 h cultivation.
\end{abstract}

Key words: Crude oil, aquatic bacteria; protein; biomass.

\section{Introduction}

Crude oil is a complex mixture that consists of hydrocarbon, (including alkanes, cycloalkanes and anomatic hydrocarbons) and nonhydrocarbon (including resin and asphalt) (Jiang et al; 2010). Crude oil is physically, chemically and biologically harmful to the environment because it contains many toxic compounds in relatively high concentrations. Ever since the discovered of oil in Nigeria in the 1950's, the country has been suffering the negative environmental consequences of oil exploration and exploitation. The growth of the country's oil industry, combined with a population explosion and lack of enforcement of environmental regulations has led to significant contamination of the environment. The effects of numerous and varied types of spillages on estuarine wetlands over the years has become a source of concern. A vast amount of petroleum wastes are produced during activities related to exploration, production refinement and transportation of oil and gas products which cause serious damage especially to the marine and estuarine environments. The major contributor to the environmental pollution is oil spillage which refers to the accidental discharge of crude oil or refined petroleum products on land or water during the process of transportation or distribution resulting in environmental pollution. This incidence of oil spillage happen in some parts of the world. Nigeria is a major exporter of crude oil and has experienced several oil spills.

Petroleum hydrocarbons are the most common environmental pollutants (ElSheshtawy et al., 2013). The contamination of habitats constitutes public health hazards. The hydrocarbons so discarded may pose serious aquatic toxicity problems. Xenobiotics may affect the microorganisms, biochemically and genetically and may also lead to inhibition of microbial growth. Pollutants many inhibit some microbial communities that are important in some biogeochemical cycles of the ecosystem as this affects microbial productivity in such ecosystem. With the development of the oil industry the general environment particularly the wetland ecosystem has become vulnerable to the toxic effects of oil pollution. Contamination of aquatic environment by crude oil and petroleum products constitute an additional source of stress to aquatic organisms (Omoregie et al., 1997).

Bacteria are ubiquitos and capable of rapid growth when provided with nutrients and conditions favourable for metabolism and cell division. Many marine bacteria have 
demonstrated the capacity to remove, under optimal conditions, some selected fractions of crude oil in a matter of days or weeks so that a certain percentage of oil by weight will disappear in a proportionate time but the remaining fractions may be more refractory to microbial attack. The abundance of bacterioplankton and phagotrophic protists in the presence of crude oil suggested enhanced carbon transfer from bacterial production to higher order organisms in an ecological loop. This maybe an important ecosystem component based on bacterial production in an oil contaminated habitat. Common crude oil degraders found in the environments are Pseudomonas, Achromobacter, Flavobacterium, Acienetobacter, Bacillus, Arthrobacter, Nocardia (Ubalua 2011). The aim of this present work was to investigate the effects of various concentrations of crude oil on biomass and protein production by some aquatic bacteria.

\section{Materials and Methods}

Bacterial isolation: Water sample was collected from Nembe River in Bayelsa State, Nigeria. This river is periodically polluted with crude oil. The sample was collected into a screw - capped conical flask at a depth of about $10 \mathrm{~cm}$ from the surface and was taken into the laboratory for microbiological analysis. About $0.1 \mathrm{~mL}$ of the water sample was plated onto Nutrient agar (Oxoid, Ltd., UK) plates containing $0.1 \%$ clotrimazole to suppress fungal contaminants. Plates were incubated at $30 \pm 2^{\circ} \mathrm{C}$ for $24 \mathrm{~h}$. Pure cultures were obtained by streaking on fresh agar plates and the isolated bacteria were identified based on the taxonomic scheme given in Bergey's Manual of Determinative Bacteriology (Holt et al., 1994).

Inoculation and biomass production: Into Nutrient broth $(100 \mathrm{~mL})$ contained in conical flasks was each added 0.5, 1.0, 1.5 and $2 \%$ $(\mathrm{v} / \mathrm{v})$ Bonny light crude oil. A control experiment devoid of crude oil was separately prepared. The medium was dispensed in 10 $\mathrm{mL}$ aliquots in test tubes and autoclaved at $121^{\circ} \mathrm{C}$ for $15 \mathrm{~min}$. The isolates were diluted to optical density (OD) 0.1 at $600 \mathrm{~nm}$ measured in a Spectrum lab 23A spectrophotometer and $0.5 \mathrm{~mL}$ aliquot was each added into the tubes. The inoculated tubes were incubated for $20 \mathrm{~h}$ at $30 \pm 2^{\circ} \mathrm{C}$ on a shaker (Fisher Roto Rack Model 343). Optical density readings were measured at $600 \mathrm{~nm}$.
Protein determination: Bacterial protein was precipitated with $10 \%$ trichloroacetic acid and determined according to the method of Lowry et al. (1951) using bovine serum albumin (Sigma-Aldrich) as a standard.

\section{Statistical Analysis}

Analysis of variance (ANOVA) and least significant difference (LSD) were used to determine the significant differences among mean values where by $p \leq 0.05$ was considered significant.

\section{Results and Discussion}

A total of three bacteria were isolated from the river sample. The bacteria were identified as Pseudomonas aeruginosa, Aeromonas hydrophyla and Vibrio fisheri. Figs. 1-3 show the average optical densities of the isolates. Biomass production by the organisms was concentration dependent. There was a correspondingly higher biomass yield of Pseudomonas aeruginosa at all concentrations of the crude oil. The best optimum growth of $0.88 \quad\left(\mathrm{OD}_{600 \mathrm{~nm}}\right)$ was observed after $20 \mathrm{~h}$ when the level of crude oil in Nutrient broth was maximum (2\%). The lowest growth of $0.77\left(\mathrm{OD}_{600 \mathrm{~nm}}\right)$ after $20 \mathrm{~h}$ was achieved when the level of crude oil in the growth medium was lowest $(0.5 \%)$. These levels were higher than control samples devoid of crude oil (Fig. 1) but showed no statistical significance. There are reports on the utilization of complex hydrocarbon mixtures like crude oil by isolated Pseudomonas species. Shailubhai et al. (1985) reported the degradation of oil sludge by pure strains of Rhodotorula rubra and Pseudomonas aeruginosa. Foght et al. (1989) reported the utilization of crude oil by pure bacterial strains of Acinetobacter calcoaceticus RAG-1 and Pseudomonas sp. HL7b. Margesin and Schinner (1999) investigated biodegradation of diesel oil by two psychotrophic bacteria that were assigned to the genera Pseudomonas sp. and Arthobacter sp. Pseudomonas was able to biodegrade crude oil and its components and used them as its sole carbon source (Leahy and Colwell, 1990). 


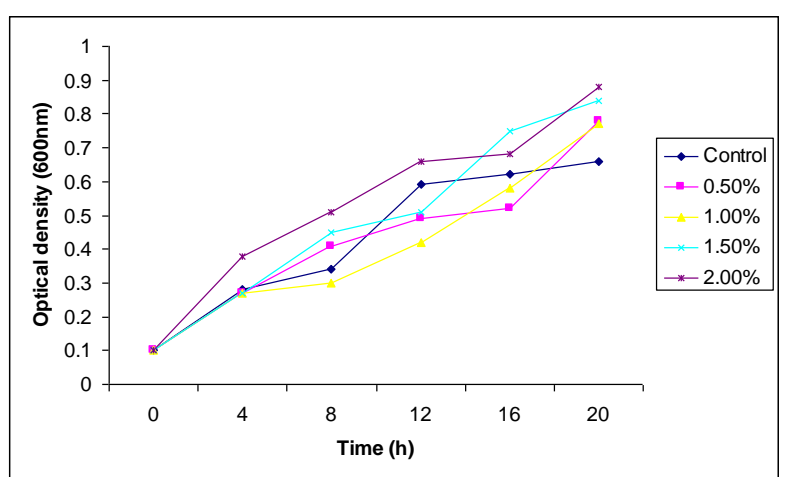

Figure 1: Effects of crude oil on biomass production by Pseudomonas aerouinosa

Figure 2 shows the effects of crude oil on biomass production by Aeromonas hydrophyla. Growth of this bacterium was low throughout the experiment. At the lowest concentration of crude oil $(0.5 \%)$, maximum biomass level of $0.58\left(\mathrm{OD}_{600 \mathrm{~nm}}\right)$ was observed after $20 \mathrm{~h}$ cultivation. This level decreased with increasing crude oil concentration (Fig. 2). Lowest growth of $0.04\left(\mathrm{OD}_{600 \mathrm{~nm}}\right)$ was observed after $20 \mathrm{~h}$ at the highest crude oil level (2\%). These levels were statistically $(p \leq 0.05)$ different from the control cultures.

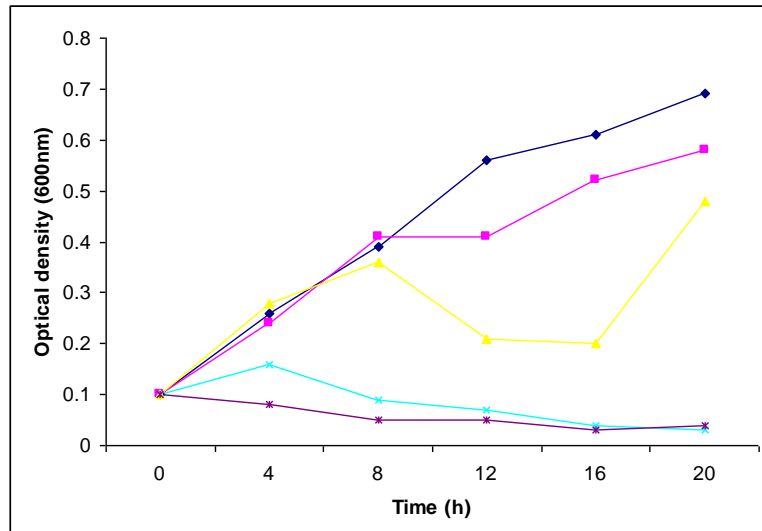

Figure 2: Effects of crude oil on biomass production by Aeromonas hydrophila

The effects of crude oil on biomass production in Vibrio fisheri culture is shown in Fig 3. Growth suppression ability of crude oil on this bacterium was evident at higher concentrations. At $0.5 \%$ crude oil concentration, maximum biomass level was produced. This level decreased progressively with increasing crude oil concentration. Maximum growth suppression occurred at the highest crude oil concentration of $2 \%$ at which the bacterial biomass level of $0.01\left(\mathrm{OD}_{600 \mathrm{~nm}}\right)$ was produced. These levels showed statistical difference $(p \leq 0.05)$ from the control samples.

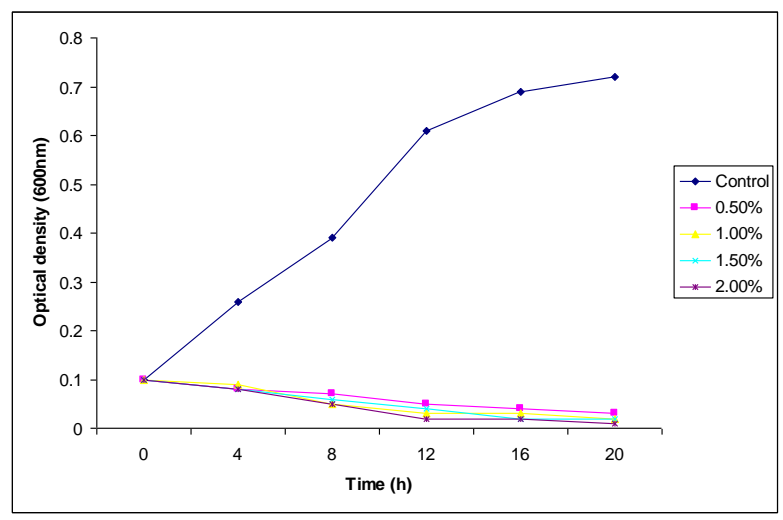

Figure 3: Effects of crude oil on biomass production by Vibrio fischeri

The concentrations of protein produced by Pseudomonas aeruginosa is shown in Fig. 4. This reveals a trend of protein increases with increases in crude oil concentration. At a crude oil concentration of $2 \%$, maximum protein production $(1.76 \mathrm{mg} / \mathrm{mL})$ was produced after $20 \mathrm{~h}$. This level was much lower at $0.5 \%$ crude oil level (Fig. 4). Control culture produced only $1.05 \mathrm{mg} / \mathrm{mL}$ of bacterial protein after $20 \mathrm{~h}$. This phenomenon was attributed to the fact that the bacterium utilized the oil as a carbon source for growth as previously reported (Leahy and Colwell, 1990).

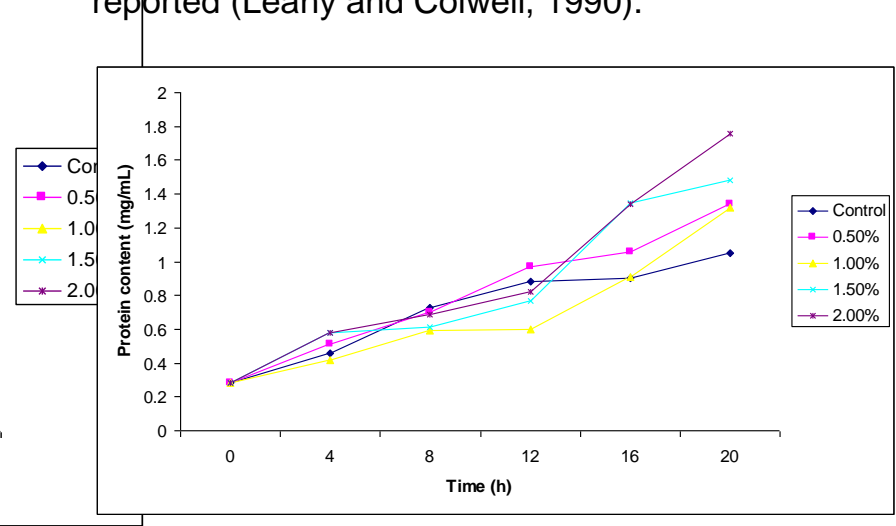

Figure 4: Effects of crude oil on protein production by Pseudomonas aeruginosa

Protein production by Aeromonas hydrophyla cultures is shown in Fig. 5. Protein content started to decrease from $0.12 \mathrm{mg} / \mathrm{mL}$ after 20 $\mathrm{h}$ at crude oil concentration of $0.5 \%$, reaching a minimum of $0.06 \mathrm{mg} / \mathrm{mL}$ after $20 \mathrm{~h}$ at a maximum crude oil concentration of $2 \%$. Protein of control cultures increased from 0.28 $\mathrm{mg} / \mathrm{mL}$ at $0 \mathrm{~h}$ to a maximum level of 1.2 $\mathrm{mg} / \mathrm{mL}$ after $20 \mathrm{~h}$. 


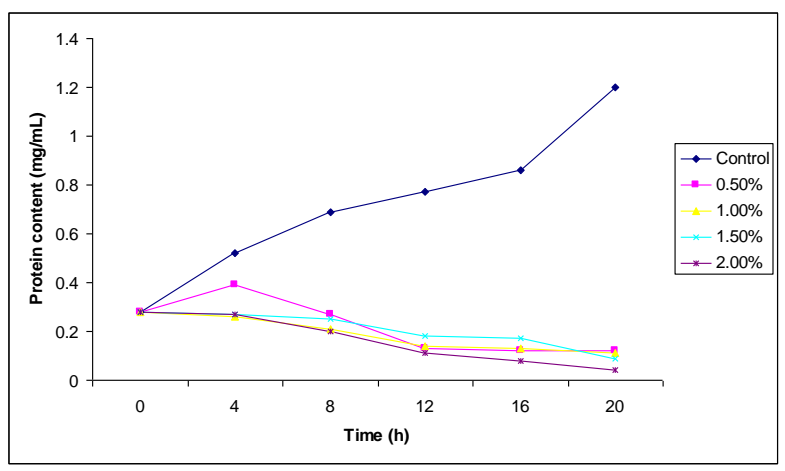

Figure 5: Effects of crude oil on protein production by Aeromonas hydrophila

The maximum protein production by culture of Vibrio fisheri was observed for control sample while that of oil treated cells gradually fell from $0.28 \mathrm{mg} / \mathrm{mL}$ at $0 \mathrm{~h}$ to $0.03 \mathrm{mg} / \mathrm{mL}$ after $20 \mathrm{~h}$ at the highest crude oil concentration of $2 \%$ (Fig. $6)$.

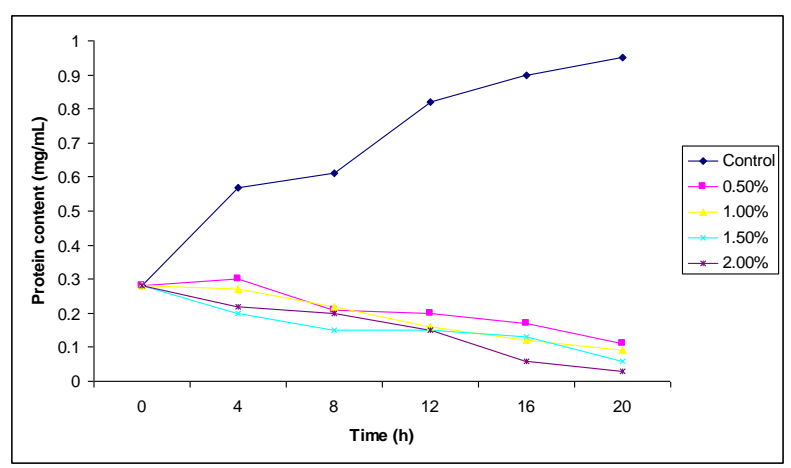

Figure 6: Effects of crude oil on protein production by Vibrio fischeri

Quantitative structure - activity relationship studies show that the toxicity of organic compounds depends primarily on the accumulation capacity in organisms and the ability to interact with the receptors (Jiang et al., 2010). There are a few reports on the toxicity of crude oil on aquatic bacteria. Most research work centers on the degradation of crude oil by bacteria (Shailubhai et al., 1985; Margesin and Schinner 1999; Mukherjee and Bordoloi, 2012). Das and Mukherjee (2007) reported that Bacillus subtilis and Pseudomonas aeruginosa utilized crude petroleum oil as sole source of carbon and energy which was evident from the increase in bacterial dry biomass, protein contents and cell density after $120 \mathrm{~h}$ incubation.

Hydrocarbons exert their toxic effects by entering the lipophilic layer of the cell membrane and preventing the transport of ions in and out of the cell. Toxicity of hydrocarbons on bacteria also occurs through disruption of cellular metabolism. Adapted microbial communities have higher proportion of hydrocarbon degraders that can respond to the presence of hydrocarbon pollutants (Okerentugba and Ezeronye, 2003). The principal forces limiting the biodegradation of polluting petroleum in the aquatic environments are the resistant and toxic components of oil itself, low water temperatures, scarcity of mineral nutrients (especially nitrogen and phosphorus), the exhaustion of dissolved oxygen, and in previously unpolluted areas, the scarcity of hydrocarbon - degrading microorganisms (Atlas, 1981). The water soluble fraction of crude oils has been found to reduce the growth rate and biomass of some bacteria. Aquatic bacterial population was reduced in stimulated oil spill experiment (Lekunberri et al., 2010). Higher concentrations of crude oil caused growth inhibition due to the higher amounts of toxic components of crude oil. Growth inhibition of bacteria at higher crude oil concentrations has been ascribed to several effects such as decreased growth rate (Amadi et al., 1996); decreased cell number (Adesina and Adelasoye 2004); decreased biomass yield (Yao et al., 2003); changes in respiration rate (Minoui et al., 2008); changes in nitrifying activity (Urakawa et al., 2012); induction of membrane toxicity (Sikkema et al., 1995); changes in bacterial activity and composition (Lekunberri et al., 2010). Biomass and protein contents of Aeromonas hydrophyla and Vibrio fisheri were lower in crude oil polluted media. It is not surprising that Pseudomonas aeruginosa produced high biomass and bacterial protein than the control at maximum crude oil level of $2 \%$. From this finding, the ability of Pseudomonas aeruginosa to produce the best biomass and protein in maximum crude oil levels was therefore related with its capacity to colonize environments contaminated with petroleum hydrocarbon and to use petroleum hydrocarbon compounds as source of carbon and energy for growth.

\section{Conclusion}

This study demonstrated that different indigenious aquatic bacteria namely Pseudomonas aeruginosa, Aeromonas hydrophyla and Vibrio fisheri responded differently to various concentrations of crude oil. Higher concentrations of crude oil decreased the growth and protein production among Aeromonas hydrophyla and Vibrio fisheri cultures. Pseudomonas aeruginosa produced maximum biomass and protein at highest crude oil levels and the values obtained for this bacterium were not significantly different in comparison to control 
cultures, devoid of crude oil. The eological implication from this study is that growth stimulation or inhibition of bacterioplankton in aquatic environments by petroleum hydrocarbon pollution could effect an imbalance on the ecological structure and trophic inter-relationship in an aquatic ecosystem.

\section{References}

Adesina, G.O. and Adelasoye, K.A (2004). Effect of crude oil pollution on heavy metal contents microbial population, maize and cowpea growth. Agricultural Scs. 5(1): $43-50$.

Amadi, A., Abbey, S.D. and Nma, A. (1996). Chronic effects of oil spill on soil properties and micro flora of a rainforest ecosystem in Nigeria. Water, Air and Soil Pollution, 86: 1 11.

Atlas, R. M. (1981). Microbial degradation of petroleum hydrocarbon: An environmental perspective. Microbial Rev. 45: 180 -209.

Das, K. and Mukherjee, A.K. (2007). Crude petroleum oil biodegradation efficiency of Bacillus subtilis and Pseudomonas aeruginosa strains isolated from a petroleum - oil contaminated soil from North-East. India. Biores. Technol. 98: $1339-1345$.

El. Sheshtawy, H.s., El - Tabei, A.S., Kobisy, A.S. and Doheim, M.M. Application of biosurfactant produced by Bacillus licheniformis and chemical surfactant in biodegradation of crude oil. Part 1. Biosciences Biotechnol. Research Asia, 10(2): 515 - 526.

Foght, J. M., Gutnick, D. L. and Westlake, D. W. S. (1989). Effect of emulsan on biodegradation of crude oil by pure and mixed bacterial cultures. Appl. Environ. Mirobiol. 55: 36-42.

Holt, J. G., Krieg, N. R., Sneath, P. H. A., Staley, J. T., Williams, S. T. (1994). Bergey's Manual of Determinative Bacteriology. Ninth edition Baltimore: Williams and Wilkins; 1994.

Jiang, Z., Huang, Y., Xu, X, Liao, Y. Shou, L., Liu, J., Chen, Q. and Zeng, J. (2010). Advances in the toxic effects of petroleum water accommodated fraction on marine plankton. Acta Ecologica Sinica, 30: 8-15.

Leahy J.G, Colwell R.R. (1990). Microbial degradation of hydrocarbons in the environment. Microbiological Reviews 54:305-315.

Lekunberri, I., Calvo-Díaz, A. Teira, E. Morán, X. A. G. Peters, F. Nieto-Cid, M. Espinoza-González, O. Teixeira I. G. and Gasol, J. M. (2010). Changes in bacterial activity and community composition caused by exposure to a simulated oil spill in microcosm and mesocosm experiments. Aquatic Microbial Ecology 59:169-183.

Margesin R., Schinner F. (1999). Biodegradation of diesel oil by coldadapted microorganisms in presence of sodium dodecyl sulfate. Chemosphere 38: 3463-3472.

Minoui, S., Minai - Tehrani, D., Zare, A. and Ahmadi, S. (2008). Effect of heavy crude oil of the pattern of respiratory chain of Pseudomonas sp. Terrestrial and Aquatic Environ. Toxicol. 2: 34 37.

Mukherjee A. K. and Bordoloi, N. K. (2012). Biodegradation of benzene, toluene and xylene (BTX) in liquid culture and in soil by Bacillus subtlis and Pseudomonas aeruginosa strains and a formulated bacterial consortium. Environ. Sci Pollut. Res. Int 19: 3380 3388.

Okerentugba P. O. and Ezeronye, O. U. (2003). Petroleum degrading potentials of single and mixed microbial cultures isolated from rivers and refinery effluent in Nigeria. Afr. J. Biotechnol. 2(9): 288 - 292.

Omoregie, E., Ufodike, B.C.O and Onwuliri, C.O.E. (1997). Effects of water soluble fractions of oil on carbohydrate reserves of Oreochromis niloficus L. J. Aquatic Sci. 12: 1-7.

Shailubhai K., Rao N., Modi V. (1985). Degradation of petroleum industry oil sludge by Rhodotorula rubra and Pseudomonas aeruginosa. Oil Petro. Pollut. 2: 133-136. 
Sikkema, J., de Bont, J. A.and Poolman, B. (1995). Mechanisms of membrane toxicity of hydrocarbons. Microbiol Rev. 59(2):201-22.

Ubalua, A.O. (2011). Bioremediation strategies for oil polluted marine ecosystems. Australian J. Agric Engineering 2: 160 $-168$.

Urakawa, H., Garcia, J. C. Barreto, P. D. Molina G. A. and Barreto, J. C. (2012). A sensitive crude oil bioassay indicates that oil spills potentially induce a change of major nitrifying prokaryotes from the archaea to the bacteria. Environmental Pollution 164:42-5.

Yao, H., Xu, J. and Huang, C. (2003). Substrate utilization pattern, biomass and activity of microbial communities in a sequence of heavy metal polluted paddy soils. Geoderma 115: 139 148. 